\title{
LEKSIKON KULINER TRADISIONAL MASYARAKAT KABUPATEN PANDEGLANG
}

\author{
Odien Rosidin, Erwin Salpa Riansi, dan Asep Muhyidin \\ Universitas Sultan Ageng Tirtayasa \\ email: odienrosidin@untirta.ac.id
}

\begin{abstract}
Abstrak
Kuliner tradisional bukan sekadar mencerminkan khazanah makanan, bahan yang digunakan, cara pengolahan, dan cita rasa olahan lokal yang unik, tetapi juga merepresentasikan entitas budaya masyarakat secara utuh. Leksikon nama kuliner tradisional menyiratkan makna budaya yang penting untuk digali dan diinterpretasikan dalam kaitannya dengan pengungkapan nilai -nilai simbolik dan budaya yang dikandungnya. Penelitian ini bertujuan mendeskripsikan kuliner tradisional masyarakat Kabupaten Pandeglang berdasarkan tinjauan bentuk leksikon, fungsinya dalam upacara atau ritual adat, dan pandangan masyarakat terhadap simbol dan makna kuliner tradisional sebagai pelengkap dalam upacara atau ritual adat.Penelitian ini didesain dengan menggunakan pendekatan kualitatif dengan memakai metode etnografis berancangan antropolinguistik. Sumber data penelitian adalah tuturan lisan para informan sebagai narasumber. Pengumpulan data dengan teknik observasi partisipan dan wawancara. Analisis data dengan empat kegiatan, yaitu pengumpulan, reduksi, penyajian, dan verifikasi. Hasilpenelitian sebagai berikut. Pertama, ditemukan 25 leksikon nama makanan; 14 leksikon nama makanan pelengkap upacara atau ritual adat; 32 leksikon nama alat pembuatan, 35 leksikon nama bahan, dan 38 leksikon nama proses pembuatan. Kedua, kuliner tradisional dalam fungsinya sebagai pelengkap upacara atau ritual adat mencerminkan tiga dimensi nilai, yaitu individual, sosial, dan pengetahuan. Ketiga, kuliner tradisional sebagai pelengkap upacara atau ritual adat merepresentasikan simbol dan makna yang berhubungan erat dengan identitas sosial budaya masyarakat Kabupaten Pandeglang. Temuan penelitian bermanfaat untuk dokumentasi produk budaya kuliner lokal dan upaya revitalisasi dan pemertahanan budaya tradisional menghadapi moderninasi dan globalisasi.
\end{abstract}

Kata kunci: leksikon, kuliner tradisional, sosial budaya, ritual adat

\section{LEXICON OF THE COMMUNITY TRADITIONAL CULINARY IN PANDEGLANG REGENCY}

\begin{abstract}
Traditional culinary not only reflects the food treasures, ingredients used, processing methods, and unique local processed flavors, but also represents the cultural entity of the community as a whole. The lexicon of traditional culinary names implies cultural
\end{abstract}


meanings that are important to explore and interpret in relation to the expression of the symbolic and cultural values they contain. This study aims to describe the traditional culinary delights of the people of Pandeglang Regency based on a review of the lexicon forms, their function in traditional ceremonies or rituals, and people's views on traditional culinary symbols and meanings as a complement to traditional ceremonies or rituals. This study was designed using a qualitative approach using ethnographic methods with anthropolinguistic design. The data source of this research was the oral speech of the informants as sources. Data collection was done byparticipant observation and interview techniques. Data were analyses were conducted in four activities, namely collection, reduction, presentation, and verification. The research results are as follows. First, the following are found: 25 lexicons of food names, 14 lexicons of names of complementary foods for traditional ceremonies or rituals, 32 lexicons of manufacturing tool names, 35 lexicons of material names, and 38 lexicons of manufacturing process names. Second, traditional culinary in its function as a complement to traditional ceremonies or rituals reflects three dimensions of value; namely individual, social, and knowledge.Third, traditional culinary as a complement to traditional ceremonies or rituals representing symbols and meanings are closely related to the socio-cultural identity of the people of Pandeglang Regency. The research findings are useful for documenting local culinary culture products and efforts to revitalize and maintain traditional culture in facing modernization and globalization.

Keywords: lexicon, traditional culinary, social culture, traditional rituals

\section{PENDAHULUAN}

Keanekaragaman kelompok etnis di Indonesia menghasilkan keragaman budaya dan adat istiadat, salah satunya budaya makan. Para antropolog memosisikan makan sebagai budaya yang sangat penting karena tidak terlepaskan dari kehidupan manusia. Caplan (1996:2) menyatakan bahwa karya-karya antropologi tentang makanan yang dipublikasikan periode1960 sampai dengan 1970-an merupakan tinggalan penting dan sangat berpengaruh. Berdasarkan kajian-kajian itu, tampak sangat jelas bahwa budaya memainkan peran yang sangat penting dalam menentukan apa yang kita klasifikasikan sebagai makanan. Menurut Montanari (2006:xi), nilai-nilai dominan dari sistem makanan dalam pengalaman manusia tidak dibatasi sebagai sesuatu yang bersifat kealamian, tetapi makanan menunjukkan proses budaya, transformasi, dan interpretasi terhadap alam.

Makanan pada dasarnya adalah produk budaya masyarakat. Makanan merupakan hasil proses konstruksi. Manusia tidak secara spontan memakan sesuatu dari alam, melainkan mengolahnya terlebih dahulu. Makanan tidak bersifat natural, tetapi artifisial. Pandangan yang mengaitkan kealamiahan dengan makanan merupakan pandangan yang keliru (Setiawan, 2016:116). Dalam antropologi, makanan dibicarakan terkait dengan teknologi dan kebudayaan fisik. Makanan 
dapat berupa sayur-sayuran, buahbuahan, akar-akaran, biji-bijian, susu, daging, ikan, dan telur. Secara garis besar, makanan dan minuman dapat dilihat dari sudut pandang teknologi, konsumsi, kegunaan, dan fungsinya (Koentjaraningrat, 1990:91). Pola dan jenis makanan menggambarkan perilaku hidup, seperti kesehatan, gaya hidup, lingkungan, dan sistem sosial. Kuliner secara budaya menggambarkan identitas lokal suatu pendukung budaya yang mencirikan lingkungan dan kebudayaan sekaligus menggambarkan representasi, regulasi, konsumsi, dan produksi (Wurianto, 2008:3-4). Oleh karena itu, dapat dirumuskan bahwa kuliner merupakan produk budaya dan berkaitan erat dengan masyarakat.

Dalam perspektif kultural, makanan dapat diklasifikasikan menjadi lima kategori, yaitu (1) makanan dan nonmakanan; (2) makanan sakral atau suci; (3) makanan pokok, makanan tambahan, dan makanan selingan; (4) makanan yang memiliki khasiat obat atau kesehatan; dan (5) makanan kategori usia (Arbai, 1997:2). Dalam semua masyarakat, makanan memainkan banyak peran dan dalam kehidupan sehari-hari, makanan sangat terikat dengan aspek sosial, agama, dan ekonomi (Helman, 1994:37). Makanan bukan hanya dipengaruhi aspek lingkungan. Munculnya ragam dan jenis makanan dipengaruhi faktor sosial budaya, seperti adat istiadat, agama, suku bangsa, ataupun kepercayaan. Masyarakat Indonesia sejak dulu telah memiliki kebudayaan yang mantap, antara lain kebiasaan mengonsumsi makanan tradisional yang berciri diproses dengan resep warisan turun-temurun, dibuat dengan alat tradisional, dan diolah dengan teknik khusus agar rasa ataupun tampilannya khas (Marwanti, 1997:9597).

Makanan tradisional atau kuliner lokal adalah produk makanan yang dikonsumsi suatu kelompok masyarakat atau dihidangkan dalam perayaan khusus pada waktu tertentu sebagai warisan dari generasi terdahulu. Jenis makanan ini dibuat dengan resep turun-temurun sehingga nyaris tanpa modifikasi dan menjadikannya berbeda dari kuliner daerah lain. Kuliner tradisional menjadi identitas lokal karena merupakan bagian dari totalitas budaya masyarakat, seperti tata cara pengolahan, peranannya dalam budaya masyarakat, dan tata perayaan dalam perhelatannya, serta resep pembuatan yang terus terjaga (Tyas, 2017:3). Kuliner atau makanan tradisional merupakan salah satu kekayaan budaya yang harus terus digali sebagai salah satu aset bangsa. Patut disayangkan, pembahasan mendalam tentang kuliner tradisional Indonesia masih tergolong langka, terutama elobarasi makna dan fungsi sosial budayanya. Kekayaan ragam kuliner Indonesia tidak dibarengi dengan upaya pemertahanan dengan cara mendokumentasikannya sebagai produk kebudayaan yang menjadi local genius suatu komunitas, baik oleh masyarakat maupun pemerintah. Berpijak pada kenyataan itu, kajian terhadap kuliner tradisional dirasa semakin mendesak dilakukan karena gencarnya serbuan kuliner asing yang berpotensi menggeser makanan tradisional sebagai kekayaan lokal sehingga terancam tidak digemari 
lagi bahkan kehilangan pamor, langka, dan punah.

Salah satu pendekatan yang dapat digunakan untuk mengkaji kuliner tradisional secara bahasa dan budaya adalah antropolinguistik. Antropolinguistik adalah studi bahasa sebagai sumber kebudayaan dan bertutur sebagai praktik kebudayaan (Duranti, 1997:2). Tujuan akhir dari studi antropolinguistik adalah mengkaji bahasa dengan cara mengambil data langsung dari penutur jati. Hal ini yang dikenal dengan etnografi atau observasi partisipan. Gagasan utama dari pendekatan ini adalah peneliti bahasa akan memahami bahasa dan hubungannya dengan seluruh aspek kebudayaan secara lebih baik dengan cara menyaksikan sendiri penggunaan bahasa dalam konteks sosial yang alamiah (Danesi, 2004:7). Studi bahasa dalam bidang antropolinguistik dikaitkan dengan peran bahasa dalam seluk-beluk kehidupan. Kebudayaan merupakan aspek paling dominan dalam kehidupan manusia sehingga secara hierarki kajian bahasa dalam bidang antropolinguistik dianalisis dalam kaitannya dengan kebudayaan (Sibarani, 2013:276). Kebudayaan merupakan sistem semiotik yang memuat simbol-simbol yang berfungsi mengekspresikan makna dari pikiran antarindividu, kebudayaan merupakan objek, tindakan, atau peristiwa yang dapat diamati, dirasakan, serta dipahami (Pranowo, 2020:54). Kebudayaan meliputi semua perbuatan manusia, misalnya cara menghayati kelahiran, kematian, dan upacaraupacara untuk menyambut peristiwa itu. Di dalam kebudayaan juga tercakup seksualitas, cara-cara mengolah makanan, sopan santun saat bersantap, pertanian, perburuan, cara membuat perkakas, pakaian, termasuk pula cara menghias rumah dan tubuh (Cathrin, 2017:32).

Penelitian terhadap makanan tradisional masyarakat Kabupaten Pandeglang penting dilakukan untuk mengisi rumpang dokumentasi khazanah sosial budaya masyarakat yang dapat diacu dalam pelbagai kepentingan. Penelitian ini diharapkan berkontribusi pada pengungkapan pandangan hidup, nilai sosial budaya, jati diri, dan keunikan masyarakat Kabupaten Pandeglang sebagai bagian dari masyarakat Indonesia yang berada di Provinsi Banten. Sejauh ini, kajian dan literatur yang membahas kuliner tradisional sebagai komunikasi simbolis yang memiliki makna filosofis, sosial, dan budaya masih terbatas. Berdasarkan penelusuran pustaka dan internet, ditemukan beberapa peneliti yang mengkaji kuliner tradisional Indonesia sebagai identitas sosial budaya.

Wurianto (2008) melakukan penelitian berjudul Aspek Budaya pada Tradisi Kuliner di Kota Malang sebagai Identitas Sosial Budaya (Sebuah Tinjauan Folklore). Penelitian ini menghasilkan temuan sebagai berikut: (1) ada keterikatan antara identitas sosial budaya, representasi sosial budaya, pola konsumsi dan produksi, serta terdapat latar belakang regulasi dalam menyepakati produk budaya yang berupa kuliner tradisional; (2) sebagai foklor nonverbal, makanan tradisional menyimpan informasi mengenai pola hidup masyarakat berdasarkan bahan-bahan makanan dan cara pengolahan makanan; (3) kuliner tradisional menggambarkan 
kearifan lokal pangan yang menginformasikan keadaan taraf atau tingkat tata kehidupan sehat, sosial, religi, dan inisiatif-inisiatif lokal; dan (4) keanekaragaman makanan tradisional yang diproduksi oleh rakyat sebagai pengetahuan tradisional dalam memanfaatkan sumber-sumber potensi ekonomi, sosial, dan budaya tidak cukup hanya diinventarisasi, melainkan perlu digali juga informasi keterkaitan pola makan dengan ketersediaan sumber pangan berbasis kekuatan dan produktivitas ekonomi.

Dengan menggunakan pendekatan etnolinguistik, Kusumaningtyas, Wibisono, dan Kusnadi (2013) melakukan penelitian berjudul Penggunaan Istilah Makanan dan Jajanan Tradisional pada Masyarakat di Kabupaten Banyuwangi Sebuah Kajian Etnolinguistik. Penelitian ini menghasilkan temuan (1) bentuk istilah makanan dan jajanan tradisional dapat diklasifikasikan menjadi kata dan frasa; (2) istilah makanan dan jajanan tradisional kaitannya dengan tradisi masyarakat Banyuwangi dapat diklasifikasikan menjadi 12, yaitu (a) tradisi pindah rumah; (b) tradisi lamaran (meminang); (c) tradisi perkawinan; (d) tradisi tujuh bulanan (Tingkeban); (e) tradisi kelahiran; (f) tradisi selapan bayi; (g) tradisi turun tanah (mudun lemah); (h) tradisi orang meninggal; (i) tradisi Maulid Nabi; (j) tradisi bulan Suro; (k) tradisi bersih desa; dan (1) tradisi kebo-keboan.

Penelitian berikutnya dilakukan Martion dan Hidajat (2014) berjudul Struktur Simbolik Kuliner Rendang di Tanah Rantau. Penelitian ini menghasilkan temuan bahwa posisi rendang sebagai kuliner lokal mampu berinteraksi simbolis dalam masyarakat global. Penelitian lain terhadap kuliner tradisional dilakukan Adrianto (2014) berjudul Jajan Pasar Makanan Tradisional Masyarakat Jawa. Penelitian ini memperoleh temuan bahwa secara faktual jajanan pasar yang ada di pasaran merupakan makanan ringan yang telah teruji karena mengalami seleksi alamiah relatif lama. Keberadaan jajanan pasar telah lama memperkaya kebudayaan daerah sesuai dengan persepsi kebudayaan Jawa. Jajanan pasar berfungsi memenuhi kebutuhan domestik dan ritual.

Selanjutnya, Setiawan (2016) melakukan penelitian berjudul Memaknai Kuliner Tradisional di Nusantara Sebuah Tinjauan Etis. Penelitian ini menghasilkan temuan bahwa (1) di balik makanan lokal di nusantara, terkandung filosofi luhur yang diwariskan turun-temurun dari nenek moyang sebagai sumber dan pedoman hidup masyarakat Indonesia. Nilai-nilailuhur itu antara lain solidaritas, gotong royong, penghargaan akan keragaman, hormat kepada sesama manusia, alam, pencipta, dan sebagainya dan (2) pelbagai persoalan etis muncul sebagai tantangan yang perlu dihadapi dalam melestarikan makanan tradisional. Anonimitas berhadapan dengan hak kekayaan intelektual, minimnya informasi sekitar kesehatan, dan keamanan produk makanan tradisional. Dilema etis seputar pelestarian kekhasan makanan tradisional, dan perlindungan terhadap kehidupan, serta praktik-praktik imperialisme dalam gaya hidup kuliner urban menjadi persoalan etis yang perlu diselesaikan bersama. 
Penelitian berupa studi literatur dilakukan Nurti (2017) berjudul Kajian Makanan dalam Perspektif Antropologi. Hasil penelitian ini menunjukkan beberapa temuan penting, yaitu (1) makanan dengan pengesahan budaya berarti berkaitan dengan kepercayaan, pantangan, aturan, teknologi, dan sebagainya yang tumbuh dan berkembang dalam sekelompok masyarakat; (2) makanan sebagai simbol-simbol tertentu memiliki makna tertentu dalam banyak aktivitas sosial; (3) makanan menjadi pembentuk identitas yang dapat dikenali dari jenis masakan yang berkarakteristik khusus; dan (4) makanan dan perubahan budaya sebagai akibat masuknya kuliner asing tidak hanya memengaruhi praktik makan sehari-hari, tetapi juga acaraacara tradisi.

Indahti, Maziyah, dan Alamsyah (2018) melakukan penelitian berjudul Makna Simbolis dan Filosofis Kuliner Tradisional pada Upacara Tradisi di Kudus. Penelitian ini menghasilkan temuan sebagai berikut: (1) tokoh utama di Kudus adalah Sunan Kudus sehingga upacara tradisi Bukak Luwur tidak akan dilaksanakan sebelum dilaksanakan upacara di makam Sunan Kudus; (2) masyarakat Kudus dan sekitarnya menganggap bahwa nasi berkat memiliki nilai simbolis dan filosofis. Nasi ini dipercayai mampu memberikan pengharapan dan memberi berkah untuk terkabulnya hajat mereka karena sudah didoakan; dan (3) kuliner tradisi dapat digunakan untuk menggali sistem budaya berupa kepercayaan yang masih tersimpan secara kolektif dalam ingatan masyarakat tersebut.

Berdasarkan tinjauan tersebut, penelitian ini memiliki perbedaan dengan penelitian-penelitian terdahulu yang diuraikan di atas. Berdasarkan ancangan teori yang digunakan, penelitian ini berbeda dengan penelitian terdahulu karena menggunakan ancangan antropolinguistik, sedangkan penelitian terdahulu menggunakan pendekatan foklore, etis, antropologi, dan etnolinguistik. Berdasarkan jenis kuliner sebagai objek kajiannya, penelitian ini bukan hanya mengkaji jajanan tradisional atau jajanan pasar dan lauk pauk, tetapi juga meliputi semua jenis kuliner, yakni kudapan, pendamping nasi, dan makanan pengganti nasi (makanan yang mengenyangkan) yang dibuat oleh masyarakat Sunda di Kabupaten Pandeglang, baik sebagai kuliner yang dikonsumsi sehari-hari maupun yang difungsikan sebagai kelengkapan upacara atau ritual adat. Berdasarkan fokus masalah kajiannya, penelitian ini berhubungan dengan bentuk leksikon tradisional, fungsi kuliner tradisional sebagai pelengkap upacara atau ritual adat, serta simbol dan makna kuliner tradisional sebagai pelengkap upacara atau ritual adat. Dengan demikian, penelitian ini memiliki dimensi analisis yang lebih luas dan mengisi rumpang atau kekosongan terhadap penelitian yang berfokus pada kuliner tradisional yang dihasilkan oleh masyarakat Sunda, khususnya yang berada di Provinsi Banten.

Penelitian ini memiliki kebaruan karena penelitian yang mengungkap permasalahan kuliner tradisional dan kuliner tradisional pelengkap upacara atau ritual adat, khususnya di Kabupaten Pandeglang dengan ancangan 
antropolinguistik belum dijangkau peneliti lain. Penelitian ini akan menjawab permasalahan sebagai berikut: (1) apa sajakah leksikon kuliner tradisional yang mencerminkan identitas sosial budaya masyarakat Kabupaten Pandeglang?; (2) apa sajakah leksikon kuliner tradisional yang melambangkan fungsi kuliner dalam upacara atau ritual adat sebagai identitas sosial budaya masyarakat Kabupaten Pandeglang?; dan (3) bagaimanakah pandangan masyarakat Kabupaten Pandeglang terhadap simbol dan makna kuliner tradisional sebagai pelengkap upacara atau ritual adat?

\section{METODE}

Penelitian ini dilaksanakan di Kabupaten Pandeglang, yang merupakan salah satu kabupaten di Provinsi Banten, Indonesia. Kabupaten ini berbatasan dengan Kabupaten Serang di Utara, Kabupaten Lebak di timur, dan Samudera Indonesia di barat dan selatan. Wilayah ini terdiri atas 35 kecamatan dan 335 desa/kelurahan. Kabupaten Pandeglang memiliki luas wilayah $2.746 .90 \mathrm{~km}^{2}$. Secara geologi, wilayah ini termasuk ke dalam zona Bogor yang merupakan jalur perbukitan. Jika dilihat dari topografi daerah, Kabupaten Pendeglang memiliki variasi ketinggian antara $0-1.778 \mathrm{~m}$ di atas permukaan laut (dpl). Sebagian besar topografi daerah ini adalah dataran rendah yang berada di daerah tengah dan selatan yang memiliki luas $85,07 \%$ dari luas keseluruhan (Banten, 2020). Penelitian ini dilaksanakan di delapan desa, yakni Desa Menes, Desa Kadubumbang, Desa Cadasari, Desa Cililitan, Desa Bojong, Desa Sukaratu,
Desa Kadubale, dan Desa Purwaraja.

Penelitian ini didesain dengan menggunakan pendekatan kualitatif dengan memakai metode etnografis berancangan antropolinguistik. Data penelitian ini adalah tuturan lisan para informan secara apa adanya yang menginformasikan bentuk leksikon, fungsi kuliner tradisional sebagai pelengkap upacara atau ritual adat, serta pandangan mereka terhadap simbol dan makna kuliner tradisional. Pengumpulan data penelitian ini dilakukan dengan teknik observasi partisipan dan wawancara. Observasi partisipan dilakukan dengan cara berperan serta atau terlibat dalam aktivitas proses pembuatan kuliner atau makanan tradisional, yakni di rumah warga yang sehari-harinya memproduksi kuliner tradisional untuk dijual (dipasarkan) dan di rumah warga yang membuat kuliner tradisional untuk kepentingan penyelenggaraan suatu perhelatan upacara atau ritual adat. Selain itu, observasi partisipan juga dilakukan dalam aktivitas mengikuti upacara atau ritual adat yang diselenggarakan oleh warga masyarakat. Wawancara dilakukan kepada para informan sebagai narasumber sebanyak 40 orang, yang dipilih dengan menggunakan teknik purposive sampling. Informan diklasifikasikan berdasarkan kriteria status sosial dan profesi, yakni (1) tokoh masyarakat, (2) tokoh agama, (3) sesepuh kampung/desa, (4) budayawan, (5) pakar atau praktisi kuliner, (6) produsen dan penjual makanan tradisional, (7) pendidik/guru, (8) aparat desa, dan (9) pegawai Dinas Pariwisata Kabupaten Pandeglang. Informan tersebut dipilih 
secara heterogen agar diperoleh data yang variatif dan komprehensif. Teknik analisis data dilakukan melalui empat tahap kegiatan, yaitu (1) pengumpulan data penelitian; (2) reduksi data penelitian; (3) penyajian data penelitian, dan (4) verifikasi. Hasil analisis data penelitian ini disajikan dengan metode penyajian informal, yakni secara verbal dengan memberikan deskripsi dan interpretasinya.

\section{HASIL DAN PEMBAHASAN}

Hasil

\section{Leksikon Nama Kuliner Tradisional}

Berdasarkan data yang diperoleh dari hasil penelitian ini, leksikon nama makanan tradisional khas masyarakat Kabupaten Pandeglang ditemukan sebanyak 25 buah. Leksikon nama makanan tradisional yang ditemukan dapat dikategorikan menurut jenisnya, yakni sebagai berikut: (1) leksikon nama makanan berjenis kudapan (makanan ringan atau cemilan); (2) leksikon nama makanan berjenis pengganti nasi (mengenyangkan); dan (3) leksikon nama makanan berjenis pendamping nasi. Oleh sebab itu, leksikon nama minuman dan jenis kuliner tradisional lainnya tidak tercakup dalam penelitian ini. Berdasarkan bentuk atau satuan lingual pembentuknya, leksikon nama makanan tradisional tersebut terbagi menjadi dua jenis, yakni (1) leksikon nama berbentuk kata sebanyak 16 buah dan (2) leksikon nama berbentuk frasa sebanyak 9 buah. Leksikon nama makanan tradisional pada Tabel 1 sampai Tabel 4

Tabel 1 Leksikon Nama Makanan Pendamping Nasi dan Kudapan Berbentuk Kata

\begin{tabular}{|c|c|c|}
\hline No. & $\begin{array}{c}\text { Leksikon Nama } \\
\text { Makanan }\end{array}$ & Kategori \\
\hline 1. & Emping & Makanan ringan/kudapan/pendamping nasi \\
\hline 2. & Jojorong & Kudapan/makanan ringan/cemilan \\
\hline 3. & Iwel & Kudapan/makanan ringan/cemilan \\
\hline 4. & Leumeung & Kudapan/makanan ringan/cemilan \\
\hline 5. & Talam & Kudapan/makanan ringan/cemilan \\
\hline 6. & Gemblong & Kudapan/makanan ringan/cemilan \\
\hline 7. & Apem & Kudapan/makanan ringan/cemilan \\
\hline 8. & Pasung & Kudapan/makanan ringan/cemilan \\
\hline 9. & Uli & Kudapan/makanan ringan/cemilan \\
\hline 10. & Opak & Kudapan/makanan ringan/cemilan \\
\hline 11. & Awug & Kudapan/makanan ringan/cemilan \\
\hline 12. & Kaniarem & Kudapan/makanan ringan/cemilan \\
\hline 13. & Sasagon & Kudapan/makanan ringan/cemilan \\
\hline 14. & Kikiping & Kudapan/makanan ringan/cemilan \\
\hline 15. & Keceprek & Kudapan/makanan ringan/cemilan \\
\hline 16. & Gipang & Kudapan/makanan ringan/cemilan \\
\hline
\end{tabular}


Tabel 2 Leksikon Nama Kudapan Berbentuk Frasa

\begin{tabular}{cll}
\hline No. & Leksikon Nama Makanan & Kategori \\
\hline 1. & Balok menes & Kudapan/Makanan ringan/cemilan \\
2. & Pais Ketug & Kudapan/Makanan ringan/cemilan \\
3. & Kue sorobaha & Kudapan/Makanan ringan/cemilan \\
\hline
\end{tabular}

Tabel 3 Leksikon Nama Makanan Pengganti Nasi Berbentuk Frasa

\begin{tabular}{cll}
\hline No. & Leksikon Nama Makanan & Kategori \\
\hline 1. & Bubur suro & Pengganti nasi/ Makanan berat (mengenyangkan) \\
2. & Bubur los & Pengganti nasi/ Makanan berat (mengenyangkan) \\
\hline
\end{tabular}

Tabel 4 Leksikon Nama Makanan Pendamping Nasi Berbentuk Frasa

\begin{tabular}{cll}
\hline No. & Leksikon Nama Makanan & Kategori \\
\hline 1. & Semur daging kebo & Makanan pendamping/pelengkap makan nasi \\
2. & Angeun lada & Makanan pendamping/pelengkap makan nasi \\
3. & Pais burih & Makanan pendamping/pelengkap makan nasi \\
4. & Stup lauk emas & Makanan pendamping/pelengkap makan nasi \\
\hline
\end{tabular}

Dalam proses pembuatan makanan tradisional yang menjadi ciri masyarakat Pandeglang tersebut, dibutuhkan alatalat khusus, baik tradisional (berbahan dari alam dan dibuat sendiri) maupun buatan pabrik/perusahaan. Leksikon nama alat-alat yang dibutuhkan untuk pembuatan kuliner tradisional yang berhasil diinventarisasi tersebut ditemukan sebanyak 32 buah. Alat-alat sebagai perkakas yang dibutuhkan dalam peroses pembuatan dan pengolahan kuliner tradisional bergantung pada bahan yang diolah dan jenis makanan yang dibuat. Leksikon nama alat-alat pembuatan kuliner tradisional masyarakat Kabupaten Pandeglang yang berhasil diinventarisasi disajikan pada Tabel 5.

Tabel 5 Leksikon Nama Alat-alat Pembuatan Kuliner Tradisional

\begin{tabular}{ccll}
\hline \multirow{2}{*}{ No. } & \multirow{2}{*}{ Leksikon Nama Makanan } & \multicolumn{2}{c}{ Leksikon Nama Alat } \\
\cline { 3 - 4 } & Balok menes & Bahasa Sunda & \multicolumn{1}{c}{ Bahasa Indonesia } \\
\hline 1. & & Katel & Lesung \\
& & Daun Cau & Kenceng \\
2. & \multirow{2}{*}{ Emping } & Palu & Daun Pisang \\
& & Dirigen & Palu \\
& & Kape & Jeriken \\
& & Keusik & - \\
& & Pasir
\end{tabular}




\begin{tabular}{|c|c|c|c|}
\hline \multirow{2}{*}{ No. } & \multirow{2}{*}{ Leksikon Nama Makanan } & \multicolumn{2}{|c|}{ Leksikon Nama Alat } \\
\hline & & Bahasa Sunda & Bahasa Indonesia \\
\hline \multirow[t]{6}{*}{3.} & Apem & Boboko & Bakul \\
\hline & & Daun Cau & Daun Pisang \\
\hline & & Citakan & Cetakan \\
\hline & & Kenceng & Kenceng \\
\hline & & Kalakat & - \\
\hline & & Hawu & Tungku \\
\hline \multirow[t]{3}{*}{4.} & Jojorong & Daun Cau & Daun Pisang \\
\hline & & Kalakat & - \\
\hline & & Langseng & Langseng \\
\hline \multirow[t]{2}{*}{5.} & Pasung & Daun Cau & Daun Pisang \\
\hline & & Kalakat & - \\
\hline 6. & Leumeung & Awi & Bambu \\
\hline \multirow[t]{2}{*}{7.} & Awug & Daun Cau & Daun Pisang \\
\hline & & Nyere & Lidi \\
\hline \multirow[t]{2}{*}{8.} & Iwel & Daun Cau & Daun Pisang \\
\hline & & Nyere & Lidi \\
\hline \multirow[t]{2}{*}{9.} & Kikiping & Daun Cau & Daun Pisang \\
\hline & & Kukusan & Kukusan \\
\hline \multirow[t]{3}{*}{10.} & Bubur los & Kenceng & Kenceng \\
\hline & & Centong & Centong \\
\hline & & Hawu & Tungku \\
\hline 11. & Bubur suro & Wajan & Wajan \\
\hline \multirow[t]{3}{*}{12.} & Opak & Irig & - \\
\hline & & Dulang & Dulang \\
\hline & & Kukusan & Kukusan \\
\hline \multirow[t]{2}{*}{13.} & Kue sorobaha & Batok Kalapa & Batok Kelapa \\
\hline & & Nyere & Lidi \\
\hline \multirow[t]{2}{*}{14.} & Kaniarem & Citakan & Cetakan \\
\hline & & Panggangan & Pemanggang \\
\hline \multirow[t]{2}{*}{15.} & Sasagon & Citakan & Cetakan \\
\hline & & Panggangan & Pemanggang \\
\hline \multirow[t]{4}{*}{16.} & Pais burih & Talenan & Talenan \\
\hline & & Peso & Pisau \\
\hline & & Daun Cau & Daun Pisang \\
\hline & & Panggangan & Pemanggang \\
\hline \multirow[t]{3}{*}{17.} & Strup ikan mas & Daun Cau & Daun Pisang \\
\hline & & Nampan & Nampan \\
\hline & & Loyang & Loyang \\
\hline \multirow[t]{2}{*}{18.} & Keceprek & Palu & Palu \\
\hline & & Nyiru & Tampah \\
\hline 19. & Pais ketug & Kalakat & - \\
\hline 20. & Talam & Loyang & Loyang \\
\hline \multirow[t]{4}{*}{21.} & Gemblong & Dulang & Dulang \\
\hline & & Langseng & Langseng \\
\hline & & Panci & Panci \\
\hline & & Halu & Lesung \\
\hline
\end{tabular}




\begin{tabular}{|c|c|c|c|}
\hline \multirow{2}{*}{ No. } & \multirow{2}{*}{ Leksikon Nama Makanan } & \multicolumn{2}{|c|}{ Leksikon Nama Alat } \\
\hline & & Bahasa Sunda & Bahasa Indonesia \\
\hline \multirow[t]{4}{*}{22.} & Uli & Dulang & Dulang \\
\hline & & Langseng & Langseng \\
\hline & & Panci & Panci \\
\hline & & Halu & Alu \\
\hline \multirow[t]{2}{*}{23.} & Semur daging kebo & Panci & Panci \\
\hline & & Kenceng & Kenceng \\
\hline 24. & Angeun lada & Pariuk & Periuk \\
\hline \multirow[t]{3}{*}{25 . } & Gipang & Citakan & Cetakan \\
\hline & & Talenan & Talenan \\
\hline & & Peso & Pisau \\
\hline
\end{tabular}

Berdasarkan temuan tersebut, terdapat beberapa leksikon nama alat atau perkakas yang tidak ditemukan padanannya dalam bahasa Indonesia. Hal itu menunjukkan bahwa alat-alat seperti kape, kalakat, dan irig merupakan kosakata budaya yang khas bagi masyarakat Sunda, khususnya di wilayah Provinsi Banten. Alat-alat itu mungkin saja terdapat di wilayah lain, misalnya Jawa Barat dengan nama yang berbedabeda, tetapi berfungsi sama. Penamaan yang khas menunjukkan keunikan budaya sebagai hasil adaptasi dan persepsi terhadap realitas atau lingkungan.

Selain membutuhkan alat-alat, proses pembuatan atau produksi makanan tradisional tersebut membutuhkan bahan-bahan utama, baik diambil dari alam (memanfaatkan potensilingkungan) maupun buatan pabrik atau industri. Leksikon nama bahan-bahan yang dibutuhkan untuk pembuatan makanan tradisional yang telah diinventarisasi ditemukan sebanyak 35 buah. Jenis bahan (utama dan campuran), komposisi, dan takaran bahan yang digunakan bergantung pada makanan yang akan dibuat dan sesuai dengan resep pembuatan yang telah diwarisi masyarakat secara turun-temurun. Leksikon nama bahan-bahan pembuatan makanan tradisional yang berhasil diinventarisasi disajikan pada Tabel 6 .

Tabel 6 Leksikon Nama Bahan Pembuatan Kudapan, Pengganti Nasi, dan Pendamping Nasi

\begin{tabular}{|c|c|c|c|}
\hline \multirow{2}{*}{ No } & \multirow{2}{*}{$\begin{array}{c}\text { Leksikon Nama } \\
\text { Makanan }\end{array}$} & \multicolumn{2}{|c|}{ Leksikon Nama Bahan } \\
\hline & & Bahasa Sunda & Bahasa Indonesia \\
\hline \multirow[t]{8}{*}{1.} & Balok menes & dangdeur & Singkong \\
\hline & & kalapa & kelapa \\
\hline & & bawang beureum & bawang merah \\
\hline & & bawang bodas & bawang putih \\
\hline & & sereh & serai \\
\hline & & laja & lengkuas \\
\hline & & katuncar & ketumbar \\
\hline & & gula beureum & gula merah \\
\hline
\end{tabular}




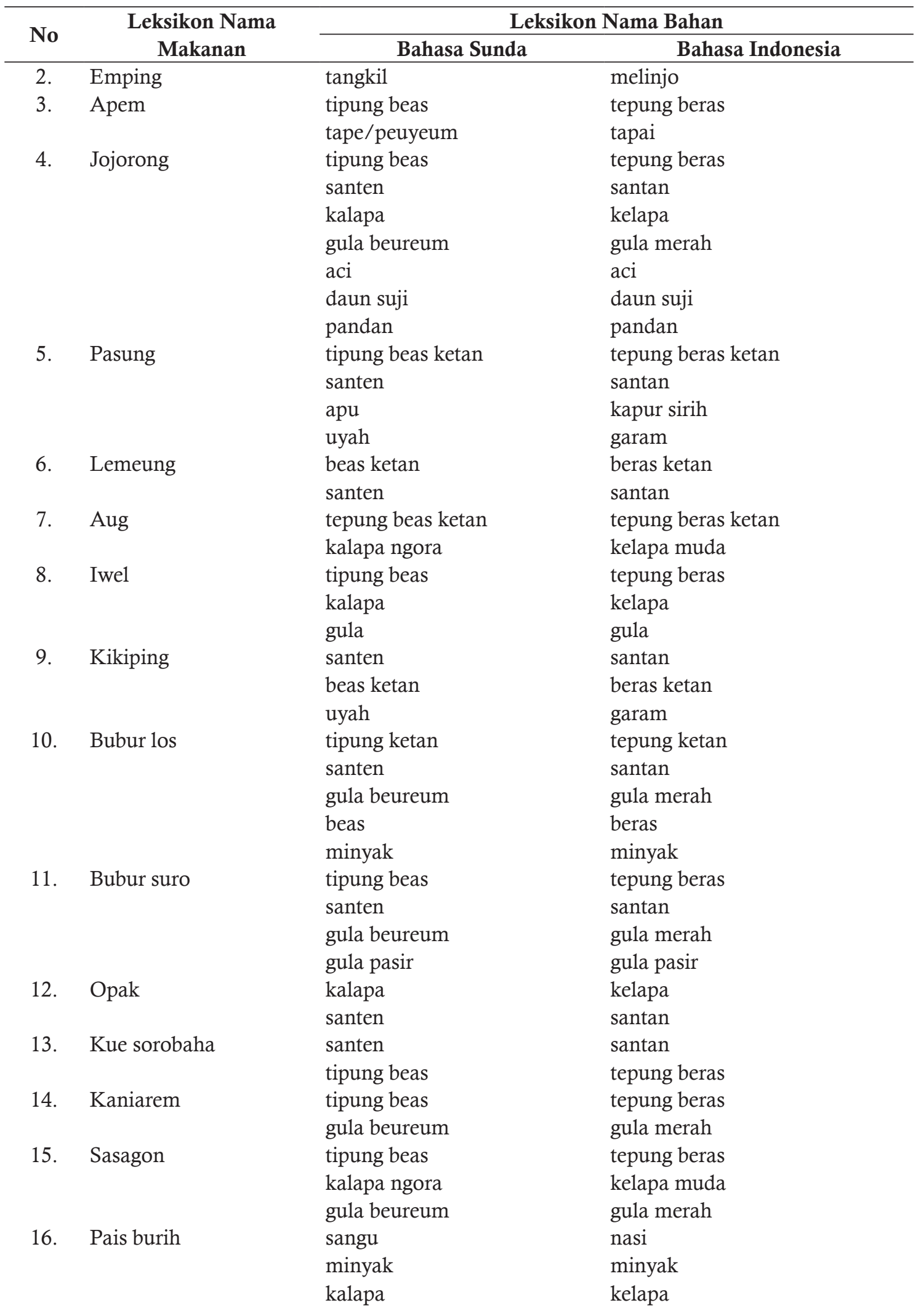

60 | LITERA, Volume 20, Nomor 1, Maret 2021 


\begin{tabular}{|c|c|c|c|}
\hline \multirow{2}{*}{ No } & \multirow{2}{*}{$\begin{array}{c}\text { Leksikon Nama } \\
\text { Makanan }\end{array}$} & \multicolumn{2}{|c|}{ Leksikon Nama Bahan } \\
\hline & & Bahasa Sunda & Bahasa Indonesia \\
\hline \multirow[t]{6}{*}{17.} & Stup lauk mas & lauk mas & ikan mas \\
\hline & & lada/pedes & merica \\
\hline & & bawang bodas & bawang putih \\
\hline & & bawang beureum & bawang merah \\
\hline & & muncang & kemiri \\
\hline & & tomat & tomat \\
\hline 18. & Keceprek & tangkil & melinjo \\
\hline \multirow[t]{4}{*}{19.} & Pais ketug & $\mathrm{cau}$ & pisang \\
\hline & & kalapa & kelapa \\
\hline & & gula beureum & gula merah \\
\hline & & aci & aci \\
\hline \multirow[t]{2}{*}{20.} & Talam & tipung beas & tepung beras \\
\hline & & pandan & pandan \\
\hline 21. & Gemblong & beas ketan & beras ketan \\
\hline 22. & Uli & beas ketan & beras ketan \\
\hline \multirow[t]{7}{*}{23.} & Semur daging kebo & cabe & cabai \\
\hline & & bawang beureum & bawang merah \\
\hline & & bawang bodas & bawang putih \\
\hline & & kecap & kecap \\
\hline & & uyah & garam \\
\hline & & kalapa & kelapa \\
\hline & & santen & santan \\
\hline \multirow[t]{10}{*}{24.} & Angeun lada & cabe beureum & cabe merah \\
\hline & & muncang & kemiri \\
\hline & & bawang beureum & bawang merah \\
\hline & & bawang bodas & bawang putih \\
\hline & & cikur & kencur \\
\hline & & koneng & kunyit \\
\hline & & daun walang & daun walang \\
\hline & & babat & babat \\
\hline & & laja & lengkuas \\
\hline & & uyah & garam \\
\hline 25. & Gipang & $\begin{array}{l}\text { beas ketan } \\
\text { gula }\end{array}$ & $\begin{array}{l}\text { beras ketan } \\
\text { gula }\end{array}$ \\
\hline
\end{tabular}

Berdasarkan temuan tersebut, singkong, kelapa, beras, beras ketan, makanan tradisional masyarakat gula, melinjo, dan ikan.

Hal lain yang berkaitan dengan Pandeglang berbasis pada pemanfaatan sumber daya alam yang dimiliki masyarakat. Dalam hal ini, bahan-bahan utama yang diolah sebagai produk kuliner pada umumnya adalah hasil alam yang mereka peroleh dari bertani, berkebun, atau budidaya, misalnya pembuatan kuliner tradisional adalah proses pembuatan yang khas dan unik sebagai bagian dari resep turun-temurun. Terkait dengan itu, leksikon nama proses pembuatan kuliner tradisional ditemukan sebanyak 38 buah. Tiap-tiap proses 
tersebut merupakan tahapan pembuatan yang penting dalam proses produksi atau pengolahan dari bahan mentah menjadi makanan siap saji. Setiap tahap dilakukan oleh orang yang memiliki keahlian dan mengetahui resepnya dengan baik karena akan menentukan hasil akhir. Leksikon proses pembuatan kuliner tradisional yang berhasil diinventarisasi disajikan pada Tabel 7.

Tabel 7 Leksikon Nama Proses Pembuatan Kudapan, Pengganti Nasi, dan Pendamping Nasi

\begin{tabular}{lll}
\hline No & Leksikon Nama Proses Pembuatan \\
\cline { 2 - 2 } & Bahasa Sunda & Bahasa Indonesia \\
\hline 1. & disangray & disangrai \\
2. & digoreng & digoreng \\
3. & dipoe & dijemur \\
4. & diseupan & dikukus \\
5. & dikulub & direbus \\
6. & ditutuan & ditumbuk \\
7. & disemur & disemur \\
8. & dikeueum & direndam \\
9. & diipiskeun & ditipiskan \\
10. & diulenkeun & diuleni \\
11. & dibungkus & dibungkus \\
12. & diparud & diparut \\
13. & dicicingkeun & didiamkan \\
14. & diongseng & digongseng \\
15. & digiling & digiling \\
16. & diperes & diperas \\
17. & dicolok & ditusuk \\
18. & diawurkeun & ditaburkan \\
19. & dienye-enye & 'ditekan-tekan hingga pipih' \\
20. & dileak & 'diratakan' \\
21. & digulung & digulung \\
22. & dikumbah & dicuci \\
23. & dikeprek & dipukul-pukul \\
24. & digalo & diaduk \\
25. & dipesek & dikupas \\
26. & dibeuleum & dipanggang \\
27. & dicitak & dicetak \\
28. & direndos & diulek \\
29. & disiksikan & diiris \\
30. & digaley & diaduk agar tercampur \\
31. & diisikan & 'dibersihkan/dicuci dengan air (berlaku bagi beras)' \\
32. & diadonan & dicampur dengan proses pengadonan' \\
33. & ditileup & dilipat \\
34. & digolakeun & \\
& & didikan \\
\hline & &
\end{tabular}




\begin{tabular}{lll}
\hline No & \multicolumn{2}{l}{ Leksikon Nama Proses Pembuatan } \\
\cline { 2 - 3 } & Bahasa Sunda & Bahasa Indonesia \\
\hline 35. & dilembutkeun & dihaluskan \\
36. & dipotongan & dipotong-potong \\
37. & dientep & disusun \\
38. & dirapihkeun & dirapikan \\
\hline
\end{tabular}

Berdasarkan temuan tersebut, dalam proses pembuatan dan pengolahan kuliner tradisional masyarakat Pandeglang, terdapat beberapa leksikon nama proses yang secara khas hanya ada atau berlaku dalam penyebutan lokal masyarakat Sunda, termasuk di Pandeglang, yaitu dienye-enye, dileak, diadonan, dan diisikan. Kekhasan nama proses pembuatan dan pengolahan tersebut menunjukkan keunikan budaya sebagai bagian dari adaptasi dan pemanfaatan sumber daya lingkungan lokal untuk keberlangsungan kehidupan. Proses pembuatan kuliner tradisional selain berhubungan dengan pengetahuan, keterampilan, dan tradisi juga merepresentasikan nilai sosial budaya yang dianut.

\section{Fungsi Kuliner Tradisional sebagai Pelengkap Upacara atau Ritual Adat}

Leksikon nama makanan tradisional yang secara budaya dipakai sebagai pelengkap upacara atau ritual adat masyarakat Kabupaten Pandeglang ditemukan sebanyak 14 buah. Tiap-tiap makanan tersebut memiliki fungsi dan nilai simbolik masing-masing. Dalam setiap upacara atau ritual adat, jenis kuliner atau makanan tradisional yang dijadikan pelengkap dapat dikategorikan menjadi dua, yaitu (1) makanan yang selalu ada atau disajikan dalam setiap upacara atau ritual apa pun dan (2) makanan yang hanya ada atau disajikan dalam acara ritual tertentu sehingga momen kemunculannya sewaktu-waktu saja. Berdasarkan satuan lingual pembentuknya, leksikon nama kuliner tradisional sebagai pelengkap upacara atau ritual adat tersebut terbagi menjadi dua jenis, yakni (1) leksikon nama makanan tradisional berbentuk kata sebanyak 10 buah dan (2) leksikon nama makanan tradisional berbentuk frasa sebanyak 4 buah. Leksikon nama berbentuk kata yang berhasil ditemukan disajikan pada Tabel 8.

Tabel 8 Leksikon Nama Kuliner Pelengkap Upacara atau Ritual Berbentuk Kata

\begin{tabular}{cll}
\hline No. & $\begin{array}{c}\text { Leksikon Nama } \\
\text { Makanan }\end{array}$ & $\begin{array}{c}\text { Nama Upacara } \\
\text { atau Ritual }\end{array}$ \\
\hline 1. & Pasung & $\begin{array}{l}\text { Selametan } \\
\text { (hajatan)/resepsi/ } \\
\text { syukuran }\end{array}$ \\
2. & Apem & $\begin{array}{l}\text { Selametan/hajatan } \\
\text { Selametan/hajatan }\end{array}$ \\
3. & Pais & Selametan/hajatan \\
4. & Jojorong & Selametan/hajatan \\
5. & Opak & pertama \\
6. & Kaniarem & Selametan/hajatan \\
7. & Kikiping & Upacara tujuh \\
& & bulanan (ritual \\
8. & & kehamilan) \\
9. & Gemblong & Selametan/hajatan \\
10. & Semuran & Lebaran \\
\hline
\end{tabular}


Adapun leksikon kuliner tradisional pelengkap upacara atau ritual adat berbentuk frasa yang ditemukan disajikan pada Tabel 9.

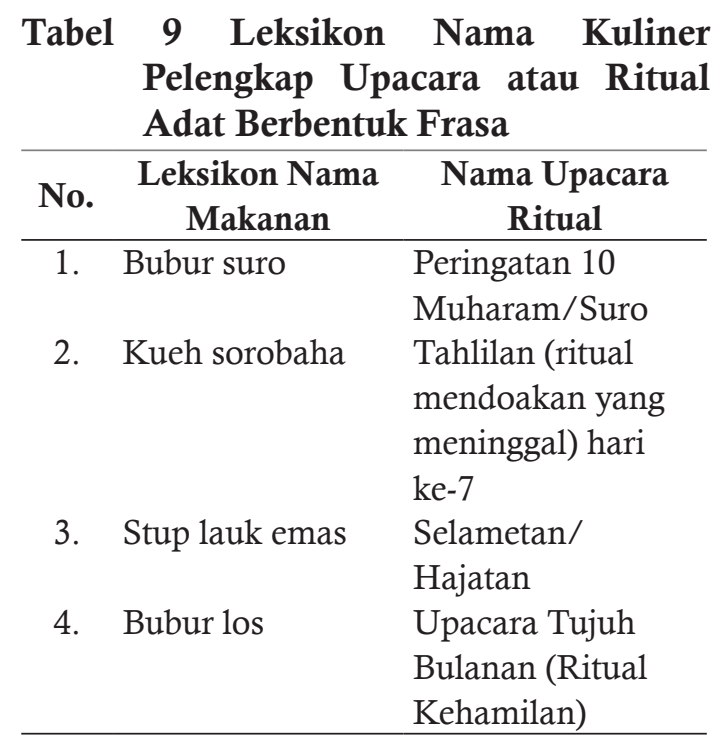

Berdasarkan hasil observasi dan wawancara, diperoleh temuan bahwa kuliner tradisional sebagai pelengkap upacara atau ritual adat masyarakat Kabupaten Pandeglang mencerminkan dimensi nilai invidual, sosial, dan pengetahuan yang khas. Selain itu, dalam pandangan masyarakat, kuliner tradisional sebagai pelengkap upacara atau ritual adat berhubungan pula dengan keyakinan atas akan adanya sanksi atau akibat bila suatu makanan tertentu tidak disajikan dalam suatu upacara atau ritual adat, baik upacara tradisional, perayaan, selametan, syukuran, maupun kegiatan tradisi lainnya. Temuan berkenaan dengan pandangan masyarakat yang mencerminkan fungsi kuliner tradisional dalam upacara atau ritual adat tersebut disajikan pada Tabel 10.

Tabel 10 Fungsi Kuliner dalam Upacara atau Ritual Adat Masyarakat Pendeglang

\begin{tabular}{|c|c|c|c|}
\hline No. & $\begin{array}{l}\text { Leksikon } \\
\text { Nama }\end{array}$ & Jenis Ritual Adat/Tradisi & Fungsi \\
\hline 1. & Pasung & $\begin{array}{l}\text { Selametan (hajatan)/ } \\
\text { resepsi/syukuran }\end{array}$ & $\begin{array}{l}\text { Ritual tidak lengkap bila makanan ini tidak } \\
\text { dibuat atau disajikan. }\end{array}$ \\
\hline 2. & Apem & Selametan/hajatan & $\begin{array}{l}\text { Ritual kurang bagus bila makanan ini tidak } \\
\text { dibuat atau disajikan. }\end{array}$ \\
\hline 3. & Pais & Selametan/hajatan & $\begin{array}{l}\text { Ritual tidak lengkap bila makanan ini tidak } \\
\text { dibuat atau disajikan. }\end{array}$ \\
\hline 4. & Jojorong & Selametan/hajatan & $\begin{array}{l}\text { Ritual tidak lengkap bila makanan ini tidak } \\
\text { dibuat atau disajikan. }\end{array}$ \\
\hline 5. & Opak & Selametan/hajatan pertama & $\begin{array}{l}\text { Makanan ini biasanya dibuat atau disajikan, } \\
\text { tetapi bila tidak dibuat atau disajikan pun tidak } \\
\text { apa-apa. }\end{array}$ \\
\hline 6. & Kaniarem & Selametan/hajatan & $\begin{array}{l}\text { Ritual dianggap kurang lengkap bila makanan } \\
\text { ini tidak disajikan. }\end{array}$ \\
\hline 7. & Kikiping & $\begin{array}{l}\text { Upacara tujuh bulanan } \\
\text { (Ritual Kehamilan) }\end{array}$ & $\begin{array}{l}\text { Makanan ini wajib ada karena sebagai syarat } \\
\text { sehingga tidak boleh tidak dibuat atau tidak } \\
\text { disajikan. }\end{array}$ \\
\hline 8. & Iwel & Selametan/hajatan & $\begin{array}{l}\text { Ritual dianggap kurang lengkap bila makanan } \\
\text { ini tidak dibuat atau disajikan. }\end{array}$ \\
\hline
\end{tabular}




\begin{tabular}{|c|c|c|c|}
\hline No. & $\begin{array}{l}\text { Leksikon } \\
\text { Nama }\end{array}$ & Jenis Ritual Adat/Tradisi & Fungsi \\
\hline 9. & Gemblong & Lebaran & $\begin{array}{l}\text { Tidak terasa Lebaran bila makanan ini tidak } \\
\text { dibuat atau disajikan. }\end{array}$ \\
\hline 10. & Semur & Lebaran & $\begin{array}{l}\text { Tidak terasa Lebaran bila makanan ini tidak } \\
\text { dibuat atau disajikan. }\end{array}$ \\
\hline 11. & Bubur suro & $\begin{array}{l}\text { Peringatan } 10 \text { Muharam/ } \\
\text { Suro }\end{array}$ & $\begin{array}{l}\text { Ritual dianggap kurang sempurna bila } \\
\text { makanan ini tidak dibuat dan disajikan sebab } \\
\text { bisa menimbulkan bahaya, bencana, atau } \\
\text { malapetaka. }\end{array}$ \\
\hline 12. & $\begin{array}{l}\text { Kueh } \\
\text { sorobaha }\end{array}$ & Tahlilan hari ke-7 & $\begin{array}{l}\text { Ritual tidak lengkap bila makanan ini tidak } \\
\text { dibuat atau disajikan. }\end{array}$ \\
\hline 13. & $\begin{array}{l}\text { Stup lauk } \\
\text { mas }\end{array}$ & Selameta/Hajatan & $\begin{array}{l}\text { Makanan ini sebagai pelengkap ritual, tetapi } \\
\text { tidak apa-apa bila tidak dibuat atau disajikan. }\end{array}$ \\
\hline 14. & Bubur los & $\begin{array}{l}\text { Upacara Tujuh Bulanan } \\
\text { (Ritual Kehamilan) }\end{array}$ & $\begin{array}{l}\text { Ritual tidak sempurna bila makanan ini tidak } \\
\text { dibuat atau disajikan. }\end{array}$ \\
\hline
\end{tabular}

\section{Simbol dan Makna Kuliner sebagai Pelengkap Upacara atau Ritual Adat}

Berdasarkan hasil observasi dan wawancara, diperoleh temuan simbol dan makna simbolik kuliner tradisional sebagai pelengkap upacara atau ritual adat masyarakat Kabupaten Pandeglang. Dari 14 buah leksikon nama makanan tradisional sebagai pelengkap upacara atau ritual adat, ditemukan seperangkat nilai simbolik yang diyakini masyarakat sebagai bagian dari falsafah dan pandangan hidup yang diwarisi secara turun-temurun dari generasi terdahulu mereka. Nilai dan makna simbolik yang berhasil diinventarisasi berdasarkan keterangan informan disajikan pada Tabel 11.

Tabel 11 Nilai Simbolik Makanan Tradisional sebagai Pelengkap Upacara atau Ritual Adat

\begin{tabular}{lll}
\hline No & \multicolumn{1}{c}{$\begin{array}{c}\text { Leksikon Nama } \\
\text { Makanan }\end{array}$} & \\
\hline 1. & Bubur suro & - Tolak bala \\
& & - Sedekah karena pada malam 10 Suro banyak kejadian \\
& & - Mengenang kisah Nabi Nuh \\
2. Pasung & - Memasung dengan harapan agar jangan jauh antarpengantinnya \\
& & - Memayungi orang meninggal \\
3. Apem & Ciri khas berbuka puasa bulan Ramadan \\
4. Pais & Makanan khas dalam tradisi adat masyarakat Pandeglang \\
5. Uli dan semur & Jamuan keluarga \\
6. Jojorong & Menyambut tamu \\
7. Gemblong dan & Jamuan keluarga \\
8. Semur daging kebo & Opak & Pelengkap makanan dalam suatu acara tradisional
\end{tabular}




\begin{tabular}{cll}
\hline No & \multicolumn{1}{c}{$\begin{array}{c}\text { Leksikon Nama } \\
\text { Makanan }\end{array}$} & \multicolumn{1}{c}{ Nilai Simbolik } \\
\hline 9. & Kue sorobaha & Makanan untuk selamatan \\
10. & Kaniarem & Menyambut tamu \\
11. & Stup lauk mas & Penyambut tamu istimewa \\
12. & Bubur los & Syarat agar kelahiran bayi lancar \\
13. & Kikiping & Biar hidup atau perilakunya seimbang antara baik dan buruk \\
14. & Iwel & Menyambut tamu \\
\hline
\end{tabular}

\section{Pembahasan}

Atas dasar analisis data di atas, leksikon nama kuliner tradisional; fungsi kuliner tradisional dalam upacara atau ritual adat; dan pandangan masyarakat terhadap simbol dan makna kuliner tradisional sebagai pelengkap upacara atau ritual adat masyarakat Kabupaten Pandeglang dapat diintrepretasikan sebagai berikut.

\section{Leksikon Nama Kuliner Tradisional}

Leksikon nama makanan bukan sekadar tata nama yang mana suka, tetapi menunjukkan makna dan nilai sosial budaya yang sangat unik dan spesifik. Leksikon nama makanan merupakan nomenklatur terhadap makanan yang diciptakan berdasarkan pertimbangan yang beragam, misalnya berdasarkan tekstur, rasa, bentuk, bahan, bumbu, proses, warna, aroma, waktu pembuatan, cara penyajian, cara menikmati, asal daerah, dan lain-lain. Dengan demikian, leksikon nama kuliner tradisional bersifat khas dan unik karena merepresentasikan nilai-nilai sosial, budaya, dan falsafah yang dimiliki dan dianut masyarakatnya.

Penelitian ini menemukan leksikon nama makanan tradisional sebagai kuliner khas masyarakat Kabupaten
Pandeglang sebanyak 25 buah dan leksikon nama makanan tradisional sebagai pelengkap upacara atau ritual adat sebanyak 14 buah. Leksikon nama makanan yang ditemukan mencakup kudapan (makanan ringan atau cemilan), lauk pendamping nasi, dan makanan pengganti nasi (makanan berat). Dari 25 buah leksikon makanan tradisional, ditemukan 32 buah leksikon nama alat yang dibutuhkan untuk proses pembuatannya, dan 35 buah leksikon nama bahan yang diperlukan untuk pembuatannya. Adapun leksikon nama proses pembuatan yang ditemukan sebanyak 38 buah. Satuan lingual yang dipakai untuk menamai makanan, alat, dan bahan pembuatan makanan adalah satuan berbentuk kata dan frasa. Adapun satuan lingual yang dipakai untuk menamai proses pembuatan adalah kata berimbuhan bentuk pasif dalam bahasa Sunda dan bahasa Indonesia. Leksikon proses pembuatan makan tradisional yang ditemukan ada yang menunjukkan proses yang khas milik masyarakat Sunda dan ada pula yang terdapat di wilayah lain di Indonesia dengan penyebutan yang berbeda sesuai dengan bahasa lokal setempat.

Dalam hubungannya dengan temuan penelitian ini, perlu dikemukakan bahwa 
penelitian ini secara khusus mengkaji khazanah leksikon makanan tradisional dan makanan pelengkap upacara atau ritual adat masyarakat Kabupaten Pandeglang. Oleh sebab itu, temuan yang bersifat kultural mungkin hanya berlaku secara unik dan khas bagi masyarakat Pandeglang sebagai bagian dari masyarakat Sunda di Provinsi Banten. Berkenaan dengan permasalahan pertama, penelitian ini menghasilkan temuan leksikon nama, bahan, proses, dan peralatan yang berhubungan dengan kuliner tradisional dan kuliner pelengkap upacara atau ritual adat masyarakat Pandeglang, baik berupa kata maupun frasa. Leksikon-leksikon tersebut tidak dapat dilepaskan dari aspek sosial budaya masyarakat mengingat makanan berada dalam jaringan kebudayaan.

Temuan tersebut membuktikan bahwa bahasa merupakan manifestasi terpenting dari kehidupan mental penuturnya. Bahasa mendasari pengklasifikasian pengalaman secara berbeda-beda. Pengklasifikasin semacam itu tidak disadari oleh penuturnya. Sejalan dengan itu, Wierzbicka (1997:1) mengemukakan bahwa terdapat hubungan yang sangat erat antara kehidupan suatu masyarakat dan leksikon bahasa yang dimilikinya. Oleh karena itu, berdasarkan leksikon nama kuliner tradisional yang ditemukan, dapat diungkap makna budaya yang menggambarkan pola hidup masyarakat Kabupaten Pandeglang berhubungan dengan pemanfaatan lingkungan untuk pemenuhan kebutuhan terhadap makanan, baik untuk kebutuhan seharihari maupun untuk upacara atau ritual adat.
Budi (2014:30) menyatakan bahwa pada makanan tradisional ditekankan adanya penggunaan bahan baku lokal, teknik pengolahan, resep pembuatan, dan cita rasa umumnya bersifat turuntemurun, serta sedikit sekali modifikasi. Hal itu tampak dalam pembuatan kuliner tradisional masyarakat Pandeglang yang merepresentasikan penggunaan bahan baku lokal berupa beras, beras ketan, singkong, kelapa, gula, melinjo, ikan, dan lain-lain; penggunaan teknik pembuatan yang khas dan tidak ditemui di wilayah lain; serta cita rasa kuliner yang unik dan tetap dipertahankan sebagaimana resep aslinya.

Berkaitan dengan penamaan makanan tradisional, temuan penelitian ini sejalan dengan pendapat Prihadi (2015:307) bahwa penamaan terhadap suatu entitas (termasuk makanan) sangat berhubungan dengan simbol dalam budaya. Sementara itu, Chaer (1995:43) menyatakan bahwa dasar penamaan yang terkait dengan mahluk, benda, aktivitas, dan peristiwa dapat ditelusuri asal-usulnya. Dasar penamaan itu adalah peniruan bunyi, maksudnya pemberian nama pada makhluk, benda, aktivitas, dan peristiwa tersebut dibentuk berdasarkan bunyi dari benda atau suara yang ditimbulkan oleh benda tersebut. Di samping itu, dasar penamaan adalah keserupaan, maksudnya pemberian nama pada makhluk, benda, aktivitas, dan peristiwa itu dapat dilakukan melalui keserupaan benda. Selanjutnya, dasar penamaan adalah tempat asal, maksudnya pemberian nama pada makhluk, benda, aktivitas, dan peristiwa itu dapat dilakukan melalui tempat di mana benda tersebut ditemukan. 
Berkaitan dengan pernyataan tersebut, terdapat leksikon nama makanan tradisional dan makanan pelengkap upacara atau ritual adat masyarakat Kabupaten Pandeglang yang dapat ditelusuri asal-usul penamaannya berdasarkan dasar keserupaan dan tempat. Penamaan berdasarkan keserupaan tampak pada penamaan kue pasung. Kue ini dinamai "pasung" karena bentuknya menyerupai pasung. Adapun penamaan berdasarkan tempat tampak pada penamaan "balok menes". Kue ini dinamai "balok menes" sesuai dengan asal-usul tempat produksinya, yakni wilayah Menes. Selain itu, ditemukan pula dasar penamaan lainnya, yakni (1) berhubungan dengan bahan dasar yang digunakan dalam pembuatanya, misalnya stup lauk mas dan semur daging kebo; (2) berhubungan dengan momen kemunculan atau pembuatannya, yaitu bubur suro; (3) berhubungan dengan tujuan atau maksud yang diharapkan dalam pembuatannya, yakni bubur los; dan (4) berhubungan dengan jenis bumbu sehingga mementukan jenis masakan yang dihasilkan, yaitu semur.

\section{Fungsi Kuliner Tradisional sebagai Pelengkap Upacara atau Ritual Adat}

Leksikon nama makanan, baik berbentuk kudapan (makanan ringan atau cemilan), makanan pengganti nasi, maupun makanan pendamping nasi yang ditemukan di lingkungan budaya masyarakat Kabupaten Pandeglang merefleksikan pengetahuan, keterampilan, tradisi, kebiasaan, kepercayaan, dan aspek budaya lainnya. Makanan tradisional tersebut tentunya diciptakan dengan memanfaatkan bahan lokal yang tersedia di alam atau lingkungan sekitar dan diproses dengan cara-cara tertentu yang diwariskan secara turun-temurun. Selain itu, terdapat jenis makanan tertentu yang bukan sekadar memenuhi kebutuhan fisik, tetapi diciptakan untuk memenuhi kebutuhan tradisi dan religi. Oleh karena itu, terdapat beberapa leksikon dan jenis kuliner tradisional yang dipakai sebagai kelengkapan upacara atau ritual adat atau muncul pada waktu-waktu tertentu saja.

Berkaitan dengan permasalahan tersebut, penelitian ini menemukan nilai individual, sosial, dan pengetahuan dari kuliner tradisional dan kuliner pelengkap upacara atau ritual adat yang merupakan identitas sosial budaya masyarakat Pandeglang. Sebagaimana diketahui, Arbai (1997:3) menyatakan bahwa makanan tradisional sudah membudaya secara domestik sejak beberapa generasi sebelumnya, diolah dari bahan yang tersedia, dan sebagian mempunyai fungsi khusus, baik sebagai makanan ritual maupun berkaitan dengan fungsi sosial budaya.

Dalam kaitan dengan fungsinya sebagai pelengkap upacara atau ritual adat, secara kultural berdasarkan keyakinan masyarakat, terungkap bahwa (1) terdapat jenis kuliner tradisional yang wajib hadir atau tidak tergantikan sebab menjadi penentu keabsahan upacara atau ritual adat yang diselenggarakan bahkan bisa menghadirkan masalah atau hal yang tidak diharapkan bila kuliner tersebut tidak dihadirkan, misalnya kikiping, bubur suro, bubur los, dan pasung; (2) terdapat jenis kuliner tradisional yang sengaja dibuat untuk menyambut bulan 
suci (Ramadan) dan hari raya Idulfitri (Lebaran), misalnya semur dan gemblong sehingga pada waktu lain jenis kuliner tersebut jarang ditemukan; dan (3) terdapat jenis kuliner tradisional yang kehadirannya dalam upacara atau ritual adat boleh ada atau boleh tidak ada. Meskipun demikian, kuliner tersebut dianggap lebih baik dan afdal bila dihadirkan, misalnya apem, pais, opak, jojorong, dan kaniarem.

Dengan demikian, temuan yang diperoleh dalam penelitian ini sejalan dengan pernyataan Koentjaraningrat (1990:186) bahwa wujud kebudayaan terbagi menjadi tiga, yaitu (1) wujud kebudayaan sebagai suatu kompleks dari ide-ide, gagasan, norma-norma, nilainilai, peraturan, dan sebagainya; (2) wujud kebudayaan sebagai suatu kompleks aktivitas kelakuan berpola dari manusia dalam masyarakat. Wujud ini berupa sistem sosial dalam masyarakat yang bersangkutan; dan (3) wujud kebudayaan sebagai benda-benda hasil karya manusia yang berupa kebudayaan fisik berbentuk nyata yang merupakan hasil karya masyarakat yang bersangkutan. Berkaitan dengan pernyataan itu, kuliner tradisional dan kuliner pelengkap upacara atau ritual adat masyarakat Kabupaten Pandeglang mencerminkan ketiga aspek kebudayaan yang dikemukakan Koentjaraningrat karena (1) merepresentasikan ide-ide, gagasan, norma-norma, nilai-nilai yang dimiliki masyarakat Kabupaten Pandeglang; (2) merepresentasikan aktivitas kelakuan berpola atau sistem sosial dalam masyarakat Kabupaten Pandeglang mengingat pembuatan makanan memiliki dimensi fungsi individual, sosial, dan pengetahuan; dan
(3) merepresentasikan kreativitas membuat benda-benda (berwujud makanan) untuk memenuhi kebutuhan sehari-hari ataupun kebutuhan perayaan yang berhubungan dengan kepercayaan, tradisi, dan religi.

Berkaitan dengan fungsi kuliner tradisional sebagai pelengkap upacara atau ritual adat, penelitian ini menemukan tiga dimensi nilai, yakni nilai yang berhubungan dengan fungsi individual, fungsi sosial, dan fungsi pengetahuan. Fungsi individual berkaitan dengan fungsi makanan untuk memenuhi keinginan, kebutuhan, dan kepuasan sendiri. Hal itu sejalan dengan fungsi primer makanan sebagai pemenuhan kebutuhan jasmani atau asupan bagi tubuh agar tidak lapar. Fungsi sosial berkaitan dengan fungsi makanan sebagai bagian dari upaya membangun suasana keguyuban, kekeluargaan, harmoni, persaudaraan, silaturahmi, dan kebersamaan. Fungsi ini secara nyata tercermin dalam makanan tradisional yang dihadirkan sebagai pelengkap dalam upacara atau ritual adat. Nilai sosial, seperti gotong royong, kebersamaan, keguyuban, dan saling menolong direalisasikan sejak proses pembuatan hingga proses menikmati sajian. Dengan demikian, nilai sosial direpresentasikan dalam proses pembuatan dan pemanfaatannya untuk orang lain, baik sebagai jamuan menghormati tamu maupun pemberian kepada orang lain (tetangga dan saudara). Nilai pengetahuan berkaitan dengan wawasan dan pengetahuan yang dimiliki oleh warga masyarakat dalam membuat produk kuliner tradisional dengan menggunakan bahan, cara, dan alat-alat yang diketahui 
bersama sebagai bagian dari tradisi masyarakat Kabupaten Pandeglang. Pengetahuan ini melahirkan makananmakanan yang khas wilayah Kabupaten Pandeglang atau makanan yang hampir sama dengan makanan di wilayah lain, baik di Provinsi Banten maupun provinsi lain di Indonesia.

\section{Simbol dan Makna Kuliner Tradisional sebagai Pelengkap Upacara atau Ritual Adat}

Makanan bukan sekadar penting untuk memenuhi kebutuhan makan, tetapi juga terkait erat dengan kebudayaan, termasuk teknologi, organisasi sosial, dan kepercayaan masyarakat. Makanan tidak bermakna apa-apa jika tidak diposisikan dalam perspektif kebudayaan atau jaringan interaksi sosialnya (Nurti, 2017:1). Dalam kaitan dengan itu, Adrianto (2014:11-13) menyatakan bahwa makanan bukan hanya untuk memenuhi kebutuhan fisik, tetapi juga kebutuhan religi, ritual, atau upacara tradisional. Makanan untuk upacara tradisional adalah makanan yang disajikan dalam rangka kegiatan sosial yang melibatkan warga masyarakat terkait dengan peristiwa-peristiwa yang berada di luar aktivitas teknis sehari-hari, tetapi mempunyai kaitan dengan kekuatan di luar diri manusia.

Berkaitan dengan upacara atau ritual adat yang dilakukan oleh masyarakat Kabupaten Pandeglang, dapat diungkap beberapa hal sebagai berikut: (1) terdapat beberapa upacara atau ritual adat yang orientasinya ditujukan untuk keselamatan pribadi dan keselamatan orang lain (warga atau masyarakat) dan (2) upacara atau ritual adat yang dilakukan masyarakat Kabupaten Pandeglang dilakukan sebagai bagian dari tradisi turun-temurun dan ditujukan untuk merawat nilai-nilai kearifan lokal. Upacara atau ritual adat dan kuliner tradisional yang dijadikan pelengkapnya sampai hari ini tetap dilestarikan oleh warga masyarakat Pandeglang sehingga masih tetap terpelihara. Upacara atau ritual adat dianggap peninggalan yang penting karena mencerminkan nilai-nilai luhur untuk menjalani kehidupan. Upacara atau ritual adat merupakan salah satu wujud peninggalan kebudayaan. Kebudayaan adalah warisan sosial yang hanya dimiliki oleh warga masyarakat pendukungnya dengan jalan mempelajari dan mewariskannya secara berkelanjutan terhadap generasi selanjutnya.

Hal di atas sejalan dengan pernyataan Peursen (1990:58) (dalam Cathrin, 2017:33) bahwa upacara tradisional adalah tradisi yang dapat dipakai sebagai sarana pelestarian kebudayan karena merupakan manifestasi kehidupan setiap orang dan kelompok. Upacara tradisional dapat difungsikan sebagai saluran untuk terjadinya pewarisan norma, adat istiadat, dan kaidah luhur yang merupakan falsafah hidup. Masalah ketiga yang diungkap dalam penelitian ini adalah hubungan leksikon makanan tradisional dan makanan pelengkap upacara atau ritual adat dengan kebudayaan masyarakat di Kabupaten Pandeglang. Penelitian ini menemukan bahwa leksikon nama makanan tradisional sebagai pelengkap upacara atau ritual adat berhubungan dengan kebudayaan masyarakat di Kabupaten Pandeglang. Hal itu tercermin dari 
pandangan masyarakat terhadap aspek simbol dan makna yang dikandung dalam leksikon makanan yang dipakai dalam pelaksanaan upacara atau ritual adat yang digelar warga masyarakat.

Pelaksanaan setiap jenis upacara atau ritual adat tidak dapat dilepaskan dari unsur makanan. Makanan bukan sekadar sesuatu untuk dikonsumsi, melainkan bagian dari kearifan lokal yang mengandung banyak nilai dan ajaran kehidupan yang sejalan dengan agama, budaya, dan aspek historis. Upacara atau ritual adat dilaksanakan dengan tahap dan kelengkapan yang sesuai dengan tradisi turun-temurun. Upacara atau ritual ini dilaksanakan untuk mendatangkan keselamatan, kebahagiaan, dan keberkahan hidup, serta harmonisasi dengan alam, baik mikrokosmos maupun makrokosmos.

Dalam kaitannya dengan upaya mengungkap kaitan kuliner tradisional dengan upacara atau ritual adat, penelitian ini menghasilkan temuan bahwa makanan tradisional digunakan sebagai pelengkap dalam upacara atau ritual adat sebagai berikut: (1) hajatan (syukuran kelahiran, khitanan; perkawinan); (2) perayaan hari besar Islam; (3) tahlilan (kematian); (4) tujuah bulanan; (5) tradisi bulan Suro, dan (6) bentuk upacara atau ritual adat lainnya. Perbedaan jenis upacara dan ritual adat mencerminkan karakteristik budaya masyarakatnya. Dalam penyelenggaraan upacara atau ritual adat, terdapat makna budaya, terutama ihwal kepercayaan untuk memperoleh keselamatan, kedamaian, kebahagiaan, dan kebaikan.

Berdasarkan pemahaman tersebut, kuliner atau makanan tradisional sebagai pelengkap upacara atau ritual adat dibuat dan disajikan bukan semata untuk dimakan atau disajikan dalam jamuan, tetapi berfungsi mengungkapkan nilai simbolik sebagai berikut: (1) tolak bala atau penolak musibah/bencana, yakni bubur Suro; (2) melambangkan pengharapan, yakni pasung; (3) melambangkan permohonan keselamatan atau kelancaran, yakni bubur los; (4) melambangkan nilai/paham yang penting untuk diketahui, yakni kikiping; (5) menghormati tamu, yakni jojorong, kaniarem, dan iwel; (6) menyambut dan menghormati bulan suci Ramadan dan hari Lebaran, yakni apem, gemblong, dan semur, (7)melancarkan hajat/maksud, yakni pasung dan sorobaha; dan (8) pengingat terhadap kebaikan, yakni kikiping dan bubur Suro.

Keseluruhan temuan tersebut menguatkan pernyataan Foster \& Anderson (1986) (dalam Nurti, 2017:2) bahwa pada dasarnya perbedaan makanan pada setiap budaya menjadikan konsep makanan berbeda dengan nutrimen (nutriment). Nutrimen adalah suatu konsep biokimia, suatu zat yang mampu memelihara dan menjaga kesehatan organisme yang mengonsumsinya, sedangkan makanan (food) adalah suatu konsep budaya. Artinya, makanan didefinisikan sebagai sesuatu yang dimakan dengan legitimasi budaya. Makanan sebagai suatu konsep budaya memiliki referensi yang lebih luas daripada soal makanan dalam pengertian nutrimen. Makanan dengan legitimasi budaya terhubung sangat erat dengan kepercayaan, pantangan, aturan, teknologi, dan lain-lain yang tumbuh dan berkembang dalam suatu komunitas sehingga menjadi label identitas yang 
unik sebagai pembeda dengan kelompok lainnya. Apa yang dinyatakan oleh Foster \& Anderson tersebut berlaku pula pada lingkup kosmologi masyarakat Sunda di Kabupaten Pandeglang. Dalam hal ini, khazanah kekayaan leksikon makanan tradisional dan relasinya secara fungsional dengan upacara atau ritual adat milik masyarakat Kabupaten Pandeglang menjadi simbol identitas sekaligus secara semiotik merefleksikan budaya hidup masyarakat dalam jejaring hubungan mereka dengan lingkungan alam (fisik), dengan sesama manusia, dan dengan Tuhan sebagai pencipta.

\section{SIMPULAN}

Makanan diperlukan oleh manusia untuk memenuhi kebutuhan ragawi sehingga dapat bertahan hidup. Namun, makanan memiliki dimensi yang lebih luas dari sekadar beracuan kebutuhan lahir manusia. Konsep makanan yang terbungkus melalui leksikon secara kultural mewadahi kognisi masyarakat sekaligus menunjukkan praktik sosial dan kultural. Oleh sebab itu, melalui kajian terhadap leksikon makanan atau kuliner tradisional, khazanah budaya suatu masyarakat atau guyub tutur dapat diungkap dan ditelusuri.

Dalam memenuhi kebutuhan terhadap makanan, manusia bukan sekadar memanfaatkan apa yang ada di lingkungan hidupnya secara alamiah. Dalam konteks itu, manusia melakukan proses penciptaan dengan berbasis pada pengetahuan dan kearifan lokal yang telah diwarisinya secara turun-temurun sehingga terjadi modifikasi dan transformasi. Dengan demikian, terciptalah aneka kreasi kuliner yang secara simbolik dan semiotik menjadi penciri identik yang khas bagi suatu komunitas sehingga diatribusi sebagai kuliner lokal atau tradisional. Melalui representasi kuliner, dapat direfleksikan aspek ekologi, sosial, dan budaya masyarakat pemiliknya mengingat kuliner tidak tercipta dari kekosongan budaya.

Produk kuliner tradisional tercipta melalui proses historis atau sejarah eksistensi yang panjang dari waktu ke waktu. Produk dan varian kuliner tradisional tercipta melalui praktik kultural yang menghadapkan manusia pada cara beradaptasi dengan lingkungan secara adaptif. Hal itu dilakukan untuk memenuhi kebutuhan yang tidak semata secara lahiriah sebab banyak produk kuliner yang secara atributif dibutuhkan untuk terlaksana dan terpenuhinya kelengkapan upacara atau ritual adat. Pada aspek inilah, eksistensi kuliner dalam lingkup budaya tradisional tidak dapat dilepaskan dari kepercayaan masyarakat secara kompleks atas suatu nilai dan norma yang dihayati serta dipatuhinya dalam lingkup budaya secara intrinsik. Pilihan jenis makanan, penamaan, proses pembuatan, alat, dan bahan pembuatan, serta pemanfatannya secara lahiriah dan untuk perlengkapan upacara atau ritual adat sesungguhnya merupakan sublimasi nilai-nilai sosial dan budaya masyarakat karena makanan berada dalam jaringan kebudayaan. Kuliner tradisional merupakan entitas kultural yang memiliki makna dan fungsi penting untuk pelestarian dan pewarisan nilai-nilai kehidupan yang luhur yang diyakini masyarakat, baik bersumber pada nilai agama, kepercayaan, sosial, budaya, maupun ekologi. 
Berdasarkan hasil analisis data dan pembahasan, penelitian ini menghasilkan tiga temuan penting yang sejalan dengan permasalahan utama yang dirumuskan. Berkaitan dengan permasalahan pertama, penelitian ini menghasilkan temuan leksikon nama, bahan, proses, dan peralatan yang berhubungan dengan kuliner tradisional dan kuliner pelengkap upacara atau ritual adat masyarakat Pandeglang, baik berupa kata maupun frasa. Leksikon-leksikon tersebut tidak dapat dilepaskan dari aspek sosial budaya masyarakat mengingat makanan berada dalam jaringan kebudayaan. Berkaitan dengan permasalahan kedua, penelitian ini menemukan nilai individual, sosial, dan pengetahuan dari kuliner tradisional yang difungsikan sebagai pelengkap upacara atau tradisi adat yang merupakan identitas sosial budaya masyarakat Pandeglang. Berkaitan dengan permasalah ketiga, penelitian ini memperoleh temuan simbol dan makna leksikon kuliner tradisional sebagai pelengkap upacara atau ritual adat masyarakat Kabupaten Pandeglang. Kuliner tradisional dalam posisinya sebagai pelengkap upacara atau ritual adat memiliki makna budaya dan fungsi penting untuk pelestarian dan pewarisan nilai-nilai kehidupan yang luhur yang diyakini masyarakat.

Temuan penelitian ini mengimplikasikan beberapa hal-hal mendasar, yakni pentingnya upaya inventarisasi dan pengungkapan makna budaya yang terkandung dalam pelbagai aspek khazanah budaya (selain kuliner tradisional) masyarakat Kabupaten Pandeglang yang belum terungkap. Hal itu penting dilakukan agar tradisi tetap lestari dan nilai-nilai lokal tetap teraktualisasikan dalam kehidupan modern dan global setakat ini, yang menempatkan lokalitas sebagai potensi dan aset berharga sebagai penciri keunikan. Kajian atau studi dengan pelbagai ancangan penting dilakukan sebagai bagian dari pemertahanan budaya lokal untuk masyarakat Kabupaten Pandeglang dalam menjalani kehidupan modern dan global sehingga tidak kehilangan arah dan identitas. Temuan penelitian ini dapat dimanfaatkan secara luas oleh pemerintah dan masyarakat untuk kepentingan pelestarian, konservasi, dan revitalisasi, serta pemertahanan kebudayaan masyarakat Kabupaten Pandeglang sebagai bagian dari masyarakat Sunda di wilayah Provinsi Banten. Penelitian ini memiliki keterbatasan dalam pelbagai hal sehingga mengimplikasikan pentingya penelitian lanjutan sebagai bagian dari upaya pendokumentasikan kekayaan lokal bagi keberlangsungan budaya tradisional di Indonesia.

\section{DAFTAR PUSTAKA}

Adrianto, A. (2014). Jajan Pasar Makanan Tradisional Masyarakat Jawa. Jantra, 11-18. http:// repositori.kem dikbud.go. id/5131/1/Jantra_Vol._9_No._1_ Juni_2014.pdf.

Banten, B. P. (2020, Juni 28). Profil Kabupaten Pandeglang. Diambil kembali dari biropemerintahan. bantenprov.go.id: https:// biropemerintahan.bantenprov.go. id/profil-kabupaten-pandeglang.

Budi, N. S. (2014). Mie Des Khas Kuliner Tradisional Pundong, Bantul, 
Yogyakarta. Jantra, 29-38. http:// repositori.kem dikbud.go. id/5131/1/Jantra_Vol._9_No._1_ Juni_2014.pdf.

Caplan, P. (1997). Approaches to the study of food, health and identity. Dalam P. Caplan, Food, Health and Identity (hal. 1-31). London: Routledge. https://www. taylorfrancis.com/books/foodh e a $1 \mathrm{t} \mathrm{h}$ - id e n t i t y - p a t caplan/10.4324/9780203443798.

Cathrin, S. (2017). Tinjauan Filsafat Kebudayaan Terhadap Upacara Adat Bersih-Desa di Desa Tawun, Kecamatan Kasreman, Kabupaten Ngawi Jawa Timur. Jurnal Filsafat, 31-64. https://jurnal.ugm.ac.id/ wisdom/article/view/22841.

Chaer, A. (1995). Pengantar Semantik Bahasa Indonesia. Jakarta: Rineka Cipta.

Danesi, M. (2004). A Basic Course in Anthropological Linguistics. Toronto, Ontario: Canadian Scholars' Press Inc.

Duranti, A. (1997). Linguistic Anthropology. New York: Cambrigde University Press.

Helman, C. G. (1994). Culture, Health, and Ilness: An Introduction to Health Professional. London: ButterworthHeinemann.

Indahtri, S., Maziyah, S., \& Alamsyah. (2018). Makna Simbolis dan Filosofis Kuliner Tradisional pada Upacara Tradisi di Kudus. Endogami: Jurnal Ilmiah Kajian Antropologi, 88101. https://ejournal.undip.ac.id/ index.php/endogami/article/ view/21332.
Koentjaraningrat. (1990). Pengantar Ilmu Antropologi. Jakarta: Rineka Cipta.

Kusumaningtyas, A., Wibisono, B., \& Kusnadi. (2013). Penggunaan Istilah Makanan dan Jajanan Tradisional pada Masyarakat di Kabupaten Banyuwangi Sebuah Kajian Etnolinguistik. PUBLIKASI $B U D A Y A$, 1-9. https://repository. u nej . a c.id/bitstream / handle/123456789/60786/ Arum $\% 20 \mathrm{Kusumaningtyas.}$ pdf?sequence $=1 \&$ isAllowed $=y$.

Martion, \& Hidajat, R. (2014). Struktur Simbolik Kuliner Rendang di Tanah Rantau. Jantra, 1-9. http:// repositori.kem dikbud.go. id/5131/1/Jantra_Vol._9_No._1_ Juni_2014.pdf.

Marwanti. (1997). Menanamkan Kebiasaan Mengkonsumsi Makanan Tradisional sebagai Aset Budaya dan Wisata Boga. Cakrawala Pendidikan, 96-101. https://journal. uny.ac.id/index.php/cp/article/ view/9267.

Moeriabrata-Arbai, A. (2017, April 21). Makanan Tradisional Makna Sosial Budaya dan Manfaatnya sebagai Makanan Sehat (Functional Food) serta Upaya Pelestariannya. Pidato Pengukuhan diucapkan pada peresmian penerimaan jabatan Guru Besar dalam Ilmu Gizi. Surabaya, Jawa Timur, Indonesia: Airlangga University Press. http://repository.unair. ac.id/72117/1/PG.-242-10-Arb-m. pdf.

Montanari, M. (2006). Food Is Culture. New York: Columbia University Press. 
Nurti, Y. (2017). Kajian Makanan dalam Perspektif Antropologi. JANTRO: JURNAL ANTROPOLOGI: Isu-Isu Sosial Budaya, 1-10. http:// jurnalantropologi.fisip.unand.ac.id/ index.php/jantro/article/view/74.

Pranowo. (2020). Perspektif Masyarakat Jawa Terhadap Pemakaian Bahasa Nonverbal: Studi Kasus Etnopragmatik. Litera, 53-70. https://journal.uny.ac.id/index. php/litera/article/view/28873/pdf.

Prihadi. (2015). Struktur Bahasa Nama Pedusunan (Kampung) di Daerah Istimewa Yogyakarta: Kajian Antropolinguistik. Litera, 307-315. https://journal.uny.ac.id/index. php/litera/article/view/7206/6211.

Setiawan, R. (2016). Memaknai Tradisi Kuliner di Nusantara: Sebuah Tinjauan Etis. Respons, 113-140. http://ejournal.atmajaya.ac.id/ index.php/response/article/ view/527.
Sibarani, R. (2013). Pendekatan Antropolinguistik dalam Menggali Kearifan Lokal sebagai Identitas Bangsa. The International Conference on Indonesian Studies: Ethnicity and Globalization (hal. 274-290). Depok: Fakultas Ilmu Pengetahuan Budaya Universitas Indonesia.

Tyas, A. S. (2017). Identifikasi Kuliner Lokal Indonesia dalam Pembelajaran Bahasa Inggris. Jurnal Pariwisata Terapan, 1-13. https://jurnal.ugm. ac.id/jpt/article/view/24970

Wierzbicka, A. (1997). Understanding Culture through Their Key Words: English, Russian, Polish, German and Japanese. New York: Oxford University Press.

Wurianto, A. B. (2008). Aspek Budaya pada Tradisi Kuliner di Kota Malang sebagai Identitas Sosial Budaya (Sebuah Tinjauan Foklore). Malang: Lembaga Penelitian Universitas Muhammadiyah Malang. 